\title{
Study on the Relationship Between Tibetan Buddhist Discipline and Temple Rules
}

\author{
Muzhen Dan \\ School of Tibetan Language and Culture \\ Northwest Minzu University \\ Lanzhou, China
}

\begin{abstract}
The discipline is one of the most important components of the Buddhist doctrine, of which the origin can be traced back to the beginning of Buddhism in India. Since then, it has been further developed during the spread of Buddhism and its extension is the temple rule. The Tibetan Buddhist discipline is an important part of Tibetan culture, and its substance of spirit is praising virtue and punishing vice, practicing good deeds, improving personality, and comprehending life. "Buddhist doctrine will exist if discipline exists while it will disappear if discipline disappears", so Buddhists abide by the discipline as their own eyes. For example, Tsongkhapa master of Gelug is a typical abstinent. Based on the analysis of the connotation of Tibetan Buddhist discipline and temple rules, this paper discusses the main source of Tibetan Buddhist discipline, the relationship between Tibetan Buddhist discipline and temple rules, the characteristics of traditional temple rules, the classification of disciplines, content of temple rules and the social functions of traditional temple rules.
\end{abstract}

Keywords-Vinaya; Buddhist discipline; temple rules; relationship

\section{INTRODUCTION}

Since Buddhism was introduced into Tibetan areas and a complete system of temple was gradually formed, the Tibetan Sangha group began to systematize its temple learning system and rules while continuing to pursue Buddhist meaning. In order to strengthen the management of temple students, all Tibetan Buddhist temples have formulated a standardized, complete and systematic management model suitable for the temple in their development. The formation of such management models has played a certain role in promoting learning doctrine and teaching, standardizing norms of behavior and setting an example. Therefore, it is crucial for the development of Tibetan Buddhism. "The orientation of standard of behavior in religious restraint is essentially the direction of the whole religious mentality."1 For Buddhism, "the Buddha adopts the principle of tact, so those who enter Buddhism must insist on discipline." 2 Therefore, the study of the development and

Yan Yaozhong. Buddhist discipline and Chinese Society. Shanghai Chinese Classics Publishing House, 2007, 11. pp. 2.

Fan Chengda. Records of Wu prefecture, in "Tianfengyuan" article of Volume 32, cited Yan Yazhong: Buddhist discipline and Chinese Society, Shanghai Chinese Classics Publishing House, 2007, 11. pp. 2. changes of Tibetan Buddhist discipline and its relationship with temple rules not only provides a deeper understanding of the development model of Tibetan Buddhist temple, but also has the guiding significance for the management and planning of temples today.

"Religion, after all, is a serious exploration and pursuit of mankind"3. Especially as Buddhism, its doctrinal philosophy gives meaning to the existence of real life by understanding the construction of this life and the afterlife. Buddhism believes that the practice and good deeds of this life can determine the fate of the afterlife, namely the meaning of "cause and effect". Buddhism's purpose is to "make people indifferent and seek for living to get rid of life and death; but it require people have mercy and universal affection to remove their distresses and become happiness" 4, so Buddhists should have a high moral goal that not only needs to relieve themselves, but also maintains the care for "how human beings can achieve their ultimate value" 5 . However, both the believers and practicing monks inevitably find it hard to restrain the unhealthy habits of themselves due to secular temptations or ignorance and infirmity of themselves, which makes the path of learning Buddha dharma full of obstacles. Therefore, compulsory discipline has the necessity of existence. According to the records of the literature, discipline were not found in the founding of Buddhism by Sakyamuni, but rather were the prescribed system for code of conduct of believers in the later development of Buddhism. "The discipline was introduced from India into China, so it is the import brought by Indian monks to China, as well as the rule that monks must fulfill to be monks. Its bondage to the monks and nuns is fundamental and doctrinal".6 Therefore, discipline also has the characteristics of regionalism. It can be said that "discipline is the rule for the life of Buddhist believers and the concrete manifestation of the outward

\footnotetext{
Rita M,Gross:Buddhism After Patriarchy,State University of New york press,Albany 1993,p306.

Wang Shouren. Collected works of Wang Yangming, Volume 9, the suggestion to meet Buddha hydrophobic, Shanghai Chinese Classics Publishing House, 1992: 294

Archie J Bamm. Comparative philosophy and comparative religion, Sichuan people's publishing house, 1996: 293

Wei Yingchun. Research on Precepts and Regulations of Buddhist Communities in Late Tang and Five Dynasties, Shanghai Chinese Classics Publishing House, 2015, 4. pp. 10.
} 
appearance of the Buddhist spirit" 7, and "it is the manifestation of religious morals in the broad sense because discipline directly aim at the flaws in human nature and is the spur for self- restraint and the pursuit of the perfection"8, so Buddhism stress that "how can the light spread and the dharmadhatu become clear if we do not behave tougher than others"9. Existence of discipline exactly laid the foundation for the believers to have such a supreme character.

From the historical context of the development of Buddhism, it can be seen that early Buddhism had already realized that "everyone has different religious beliefs, but there are some similar moral codes in spiritual cultivation".10 Therefore, Mr. Fu Weixun said: "Among all religions, Buddhism can best avoid theoretical arbitrariness or dominance. It has open mind and accommodating in thinking and can easily communicate with other religions in order to seek self-improvement and self-innovation"11. This is evidenced by the development and communication of Buddhism in the later period. For example, after Buddhism was introduced into Tibet during the Tubo period, Tsampu skillfully used the social needs of Tubo and the respective advantages of Indian Buddhism proceeding from the reality of Tubo to create a developing route of Buddhism suitable for the social situation of Tubo, realizing the Tubolization of Buddhism, which is also the manifestation of flexibility of Buddhism. Buddhism has been in Tibet for more than a thousand years since it was introduced in Tubo period and kept developing whether when political power changes or social changes. It can deeply root in Tibetan areas because "Buddhism has infiltrated and even gained dominance in all cultures from the understanding and compromise that it gained in various cultures, and it has proven itself to be one of the most adaptive religions in the world." 12 It is precisely because Buddhism shows "very important coordination that allows different concepts to be reconciled, so there can be different religious sects, all of which have their own Vinaya"13.

Buddhist scriptures of Buddhism can be divided into Tipitaka of sculpture, rule and theory, treasure, and miscellaneous collections"14, which is the core content of Buddhism that will not change no matter where it is spread or in what way it develops. Among them, discipline books are the guides to the practice of these theories, so there is the

\footnotetext{
Shangtian Tianrui. History of discipline. article 1 of chapter 1 , three provinces in Tokyo Showa in the 25th year of Zhao He, pp.8

8 Yan Yaozhong. Buddhist discipline and Chinese Society. Shanghai Chinese Classics Publishing House, 2007, 11. pp. 2.

See S. 373 Datang three Tibetan question Xishe eye tower in The Collection of Dunhuang Social and Historical Documents in British Tibet, volume 2, Social Sciences Academic Press, 2003: 198.

10 Zhang Jinghe. History of Sinology in Sweden, Chapter 1, Anhui literature and art publishing house. 1995, pp. 11.

${ }^{11}$ Fu Weixun. The dignity of death and the dignity of life, Peking University Press, 2006, pp.86.

12 Archie J Bamm. Comparative philosophy and comparative religion, Sichuan people's publishing house, 1996: 184.

13 Paul Williams:Mahayana Buddhism,Routledge,London and New York,1989,p:5

14 Zhang Zhigang. Main idea of Religious research. Peking University Press, 2013, 1, pp. 20.
}

regulation of "taking discipline as teachers".15 Because the human's belief has both holiness and secularism, but "Buddhism can only embody its holiness in secularism"16, discipline precisely achieves the holiness of belief through regulating believer's behavior in the secular life. The reason why discipline is "an important part of the three schools of Buddhism"17 is that only systematic and complete discipline can guarantee the steady development of the Buddhism and Buddhist sites and groups in the norms and institutions, and give consideration to the long-term spread of the development of doctrine in a stable external environment. The development history of Buddhism for thousands of years also shows that discipline has its scientificity and it is one of the motives for the guarantee and promotion of the development of Buddhism.

\section{ThE CONNOTATION OF TIBETAN BUDDHIST DISCIPLINE}

Tibetan Buddhism is a product of long-term struggle and integration of Bon religion, the native religion in Tibet and Buddhism after its introduction to Tibet, with extremely strong regional characteristics. "Based on the doctrine of Buddhism, it absorbs some gods and rituals of the religion to form a unique and distinctive doctrine with clear cohesion and first manifestation."18 After Buddhism was introduced to Tubo in the period of Zanpu of Tubo Srongtsen Gampo, it was carried forward by later interpreters and scholars including Shantarakshita and padmasambhava, and thus Tibetan Buddhism finally came to dominant position. In the ninth century $\mathrm{AD}$, in the period of Zanpu of Tubo Glandarma, Buddhism was destroyed, and then Tubo Dynasty collapsed, followed by the end of the "prehistoric period" of spread of Buddhism in Tibet. Buddhism came into the area of Tibet from Dokham (called "Xialu" in academic circle) and Ali (called "Shanglu" in academic circle) respectively at the end of the 10th century AD. Buddhism flourished again in Tibetan areas and entered so-called "phyi dar period" in the academic circle. Subsequently, in the long course of history, Buddhism gradually formed different sects of Nyingma, Kadam, Sakya and Gelug in Tibet.

As mentioned above, discipline is one of the driving forces behind the development of Buddhism. In the history of the spread of Buddhism, discipline has gained a leading role. The original Buddhist Vinaya is divided into: Vinayapitaka, discipline, theory of law. The Vinaya is one of the Buddhist Tripitaka, transliterated by the Penayyer, or by the Punjab, referring to Terma. It is "dul ba'i sde snod" in Tibetan. The discipline is "the Khalsa regulation made for the Buddha to regulate followers' troubles and punish the bad

15 (Yuan Dynasty) De Hui, Li Jiwu. Monastic rules for Buddhists made by Laxiu Baizhang, Zhongzhou Ancient Books Publishing House, 2011, 7, pp. 1.

16 (Yuan Dynasty) De Hui, Li Jiwu. Monastic rules for Buddhists made by Laxiu Baizhang, Zhongzhou Ancient Books Publishing House, 2011, 7, pp. 3 .

17 (Song Dynasty) Zong Ze, Su Jun. regulations of Zen garden Zhongzhou Ancient Books Publishing House, 2006, 1, pp. 178.

18 Zhang Zhigang. Main idea of Religious research. Peking University Press, 2013, 1, pp. 16. 
life habits."19 That is to say, in the course of practicing, the Buddha regulates the rules aiming for the physical and psychological defects of followers in practicing and learning. They will be punished as soon as they make mistakes, which belonging to Yamas according to fate. The "Vinaya are ancient books and records sorting out tsila-dhamma made by Buddha."Discipline" is interpreted by the Vinaya, and Vinaya is the root books and records of "discipline" 20.

Vinaya is the discipline recording the life of Buddhist Bhikkhuni and Bhikkhu and it also records the discipline and criterion of behavior moral used by Buddha for his followers. At the same time, it records the course of Buddha's Dharma promotion at that time. Therefore, the content in Vinaya is of great historical value for understanding the history, customs, culture, arts and science of India at the time. Generally, Buddhist scholars believe that no discipline has been enacted or made within 20 years after the enlightenment of Buddha. Later, in the process of dissemination of Buddhism, the continuous increasing study group following the Buddhist monks grows bigger and bigger, so because of the need of code of conduct and group management, the Buddha began to make discipline for the Sangha. At that time, the discipline has its own arbitrary and subjectivity without any prior planning and consideration. It is often set randomly because of the situation the followers meet. Later, in the process of the development of Buddhism, it was gradually classified as broad Vinaya, classics of dicipline and theory of law.

In the Tripitaka Classics of Buddhism, there are five types of people including Buddha, followers and celestia in "Sutra", while "Vinaya" is "only regulated by Buddhism". According to the record of "Dharmagupta-vinaya", the Buddha made discipline 20 years after the enlightenment of Buddha, which is due to that Zuwaytina commit obscene behavior. At that time, the Buddha's intention of enacting the discipline was specifically for the purpose of long life of the monks, so "monks will exist if discipline exists and law will exist if monks exist."21 The author also think that over the more than 2,500 years development of Buddhism, Buddhist followers can still see and hear Buddhist disciples so far, which is also because of the Buddha's "monk".

According to Huada Dorje's research, the formation of Vinaya goes through a long process from no discipline to systematization, institutionalization and theorization of discipline. He believes that among the three mainstream of Buddhism, "Vinaya of Southern Buddhism is the most oldest and applied longest", "discipline of Chinese Buddhism is the most extensive". Relatively, Tibetan Buddhism formed late, so it directly absorbed many essence of Hinduism"22. As we all know, Tibetan Buddhism is dominated by the discipline of mulasarvastivada (gzhi thams cad yod par smra ba), and

19 Warhol dorje, Wei Changcheng. A Study of Temple rules in Tibetan Buddhist Temples. Tibetan Plateau Forum, 2012, 12(4): pp. 51.

20 Warhol dorje, Wei Changcheng. A Study of Temple rules in Tibetan Buddhist Temples. Tibetan Plateau Forum, 2012, 12(4): pp. 51.

21 Warhol dorje, Wei Changcheng. A Study of Temple rules in Tibetan Buddhist Temples. Tibetan Plateau Forum, 2012, 12(4): pp. 51.

22 Warhol dorje, Wei Changcheng. A Study of Temple rules in Tibetan Buddhist Temples. Tibetan Plateau Forum, 2012, 12(4): pp. 52. selectively absorbs the discipline of other sects to form its own unique system of Tibetan Buddhism. Tibetan Buddhism is out of discipline of Exotoric Buddhism, but because of the prevalence of Esoteric Buddhism, it is also concerned about the shamisen and fourteen fundamental disciplines.

According to the record in many Tibetan Buddhists history, disciplines of Buddhism are divided into the following categories due to differences in the identities of followers (Buddhists) and their grades:

- There are four types of disciplne without becoming a buddhist: three percepts (Skyabs' gro'i sdom) (2) five precepts; (bslab khrims lnga) (3) eight disciplines (snyung gnas sdom pa brgyad); (4) Bodhisattva vow (byang sems kyi sdom pa). 2. There are five kinds of disciplines for becoming a Buddhist (dge tshul gyi s pa pa): (1) Sami and shamanic percepts (dge tshul dang dge tshul ma'i s pa pa); (2)Sikkhamana percpets (dge slob ma'i s pa pa); (3) bhikkuni percepts (dge slong ma'i sdom pa); (4) Bhikkhu percepts (dge slong gi sdom pa); (5) Bodhisattva vow.

After the introduction of Buddhism into Tubo, the translation of Vinaya was mainly based on mulasarvastivada. This belongs to Vinaya of the primitive Buddhism in the Kangyur tripitaka. The following five are cited: "First, disciplines of branches (dul ba rnam par 'byed pa), disciplines for monks and nuns; Second, discipline of fundamental points (' dul ba'i gzhi); Third, discipline for matters; four, completen disciplines (gzhung blo; five, 'dul ba bsdus pa. The first to the fourth are equal to all the Chinese translation of Vinaya. The fifth is equivalent to 'fundamental Sawa multi-law' 14 volumes of Shengyouzun translated by Yi Jing 23

In fact, during the early period of promotion of Buddhism in Tubo, the discipline of Buddhism mainly consisted of relatively concise contents such as Ten Good Laws, which were further promoted step by step. The following aspects were mainly focused on:

First, discipline at home: based on three laws, five precepts and ten good laws. The three precepts: convert to Buddhism, convert to dharma, and convert to monk or change irregularly, sabbe dhamma anatta, all loves are bitter, wantaj-nirvanam. Five precepts is dge bsnyen gyi srung bya lnga: no killing, no stealing no sexual misconduct, no reckless speech, and no intoxicants. Ten good is: no killing, no stealing no sexual misconduct, no reckless speech, no flattery, no gossip, no harsh speech, no mean, no kruddhi, and no wrong view.

- The dharma of Bodhisattva vow: four heavy and forty three lights. In the area of Chinese Buddhism,

23 Suonan Cairang. General Introduction of thoughts of Tsongkhapa discipline. Qinghai Social Sciences, 1990 (5): 104. 
"Bodhisattva vow of Brahma Net" 24 is mainly promoted while in Tibetan Buddhism area, the most prevalent one is "Yoga Bodhisattva vow" and the related annotations and translations occupies a considerable proportion in classics of Tibetan Buddhism, at least eighty or ninety, such as "study on Bodhisattva vow" of the founder of Gelug, Tsongkhapa. The most basic precepts of Buddhism are the four heavy phas pham pa bzhi - "kill, steal, prostitution, jump, boldness". The 43 light of "Yoga Bodhisattva vow" is made based on the "six releases and four perturbation" that the Bodhisattva should follow. Alms giving is the first of the six releases, and there are seven articles related to alms giving in "Yoga Bodhisattva vow" (rnam 'byor byang sems kyi sdom pa), and seven items about Sila; four items are about Ksanti; three are about pure static; five are on the Buddhist meditation practice; six are for the development of of wisdom of Prajna; the other is the relevant content combining four perturbation. Therefore, the four heavy and forty-three light of the Bodhisattva vow on the one hand helps to overcome the problems of greed, angry and delusion. On the other hand, it plays an important role in understanding and developing the six releases of four perturbations.

- The discipline of Esoteric-yana: The Samaya Precept, of which the main content is fourteen basic precepts. According to the records of Buddhist theory, fourteen basic precepts are: 1. defamation of Guru, 2. Violation of Buddha dharma, 3. angry and hate to Buddhism, 4. Give up kindness, 5. Give up bodhichitta, 6. defaming sect 7 . Divulge secret, 8 . Defamation of five aggregates, 9 suspicion for Buddha dharma, 10. Not releasing the evil, 11. Appraising right dharma, 12. Making people tired, 13. Refusing the relics, 14. Defamation of women. These fourteen fundamental precepts are the most basic and most fundamental discipline of Vajrayana, and all those Practitioner of esoteric Dharma are required to keep the fourteen precepts unswervingly and shield and sustain the discipline with great care. No matter what kind of sects, what kind of classification, all Esoteric-yana recognize and abide by these fourteen fundamental rules.

As many Buddhist scholars and historians agree, Master Tsongkhapa is a reformer of Tibetan Buddhism and is known for his strict precepts. The master once proclaimed "on discipline" (dul ba mdo rtsa), "Bodhisattva discipline" (byang chub sems dpa'i sdom khrims), "Fifty songs of the ministry" (bla ma lnga bcu ba), "Fourteen fundamental Precepts of Vajrayana" to emphasize the importance of precepts. In "eulogy on sea heart" (dul ba rgya mtsho snying bo'i Tik + ka), the Master stipulates "eight kinds of precepts, including those living nearby, near man,

24 Warhol dorje, Wei Changcheng. A Study of Temple rules in Tibetan Buddhist Temples. Tibetan Plateau Forum, 2012, 12(4): pp. 52. near woman, samanera, female sami, female orthodox knowledge, Bhikkhu female, Bhikkhu discipline".25 The author tries to explain in the form of "Table I":

TABLE I. NAME OF PRECEPTS AND THE CONTENT

\begin{tabular}{|c|c|}
\hline Name of Precepts & Content \\
\hline $\begin{array}{l}\text { living } \quad \text { nearby } \\
\text { precept } \quad \text { (bsnyen } \\
\text { gnas kyi sdom pa) }\end{array}$ & $\begin{array}{l}\text { leaving brahmacariya (mi tshangs spyod pa), no } \\
\text { stealing, no killing, no nonsense (rdzun du smra } \\
\text { ba), no sleeping in high bed (mal che mtho ba), } \\
\text { no intoxicants, no greed for dance (bro dang rol } \\
\text { mor mi chags pa), having no meal after noon } \\
\text { time ('i kha zas spangs pa). }\end{array}$ \\
\hline $\begin{array}{lr}\text { Recent } & \text { Things } \\
\text { precepts } & (\text { dge } \\
\text { bsnyen } & \text { gyi } \\
\text { sdom pa })\end{array}$ & $\begin{array}{l}\text { No killing, no stealing, no reckless speech (log } \\
\text { par g.yem pa), no wrong view (log par mi spyod } \\
\text { pa), no intoxicants. }\end{array}$ \\
\hline $\begin{array}{l}\text { Sramanera Precepts } \\
\text { (dge tshul gyi } \\
\text { khrims) }\end{array}$ & $\begin{array}{l}\text { Away from the non-brahmacariya (yang dag par } \\
\text { spyod pa), no stealing, no killing (yang dag par } \\
\text { spyod pa), no reckless speech, no intoxicants, no } \\
\text { sleeping in high bed, no song and dance, no } \\
\text { paint flowers vase (phreng sogs), having no } \\
\text { meal after noon time (phyi dro'i kha zas spangs } \\
\text { pa), no greed for silver and gold. (or no killing, } \\
\text { no stealing no sexual misconduct, no reckless } \\
\text { speech, no flattery, no gossip, no harsh speech, } \\
\text { no mean, no kruddhi, no wrong view and no } \\
\text { wrong close.) ) }\end{array}$ \\
\hline $\begin{array}{l}\text { Female } \quad \text { student } \\
\text { precept (dge } \quad \text { slob } \\
\text { ma'i sdom pa) }\end{array}$ & $\begin{array}{l}\text { No walking alone (gcig pur lam du mi 'gro ba), } \\
\text { no crossing water alone (chu ba'i pha rol rkyal } \\
\text { mi bya), no touching male and living with male } \\
\text { (skyes pa la ni reg mi bya), no marriage (gnyen } \\
\text { du 'gyur ba mi bya), no conducting crime (kha } \\
\text { na ma tho 'chab mi bya), no catching gold and } \\
\text { silver and no invisible hairs ('doms kyi spu ni } \\
\text { breg mi bya), having to eat, no eating left food } \\
\text { (gsog' jog byas pa bza 'mi bya), raw grass is not } \\
\text { net, so we should not dig the ground (sa ni rko } \\
\text { bar mi bya ba). (The first six are six basic } \\
\text { precepts, and the latter six are six } \\
\text { Dharmanudharmapatipatti.) ) }\end{array}$ \\
\hline $\begin{array}{l}\text { Bhikkhuni discipline } \\
\text { (dge slong ma'i } \\
\text { sdom pa) }\end{array}$ & $\begin{array}{l}\text { Totally three hundred and sixty-four precepts } \\
\text { including eight heavy (pham brgyad), twenty } \\
\text { remnant (lhag ma nyi shu), thirty giving up } \\
\text { degeneration (spangs ba'i ltung byed sum cu), } \\
\text { eighty single degeneration (ung by by 'ba' zhig } \\
\text { brgyad bcu), eleven regret (so sor bshags pa bcu } \\
\text { gcig), one hundred and twelve duskrta (nyes } \\
\text { byas brgya bcu gnyis). }\end{array}$ \\
\hline $\begin{array}{l}\text { Bhikkhu } \text { precepts } \\
\text { (dge slong gi } \\
\text { khrims) }\end{array}$ & $\begin{array}{l}\text { Bhikkhu precepts four heavy (pham pa bzhi), } \\
\text { thirteen remnant (bcu gsum spang ltung), thirty } \\
\text { giving up degeneration (spang ltung sum cu), } \\
\text { ninety single degeneration (ltung byed 'ba' zhig } \\
\text { dgu bcu), four regret (sor bshags bzhi), one } \\
\text { hundred and twelve duskrta, totally two hundred } \\
\text { and fifty-three precepts. }\end{array}$ \\
\hline
\end{tabular}

In general, the essence of the precepts, whether for Tibetan Buddhism, Chinese Buddhism, or Southern Buddhism, lies in regulating believers' behaviors and thoughts in the process of learning Buddhism and spiritual practice. Therefore, as long as one believes in Buddhism, no matter the people practicing at home or becoming a monk, they have systematic discipline respectively. As mentioned

25 Archives of Tibet Autonomous Region. "Tibetan Local History Collection Temple Rules" (Tibetan version), Tibet people's publishing house, 2012, 1: 790 . 
above, there are also different corresponding precepts at different levels of practice. However, discipline is the code of conduct that individuals in collective life should follow, which are macroscopic and lack specific provisions. Temple rules are not the same, since it specifically aims for the detail level in personal life, and has its own regional characteristics. It can be said it makes up for lack of implementation of discipline in specific operation. With the development of society and the changes of the times, the ancient discipline can no longer cover all aspects of the behavioral norms in the collective life of the monks. The management mode of the monastery urgently needs to be systematized according to the local conditions and the times so that the temple rules came into being in the complicated social changes.

\section{CONNOTATION OF TEMPLE RULES OF TIBETAN BUDDHISM}

Temple rule of Tibetan Buddhism is formulated mainly taking the discipline of Buddhism as the principle and it is the development and extension of Buddhist discipline, or it can be said that "Temple rule is the textual system formulated by venerable Living Buddha of temple or renowned Grand Lama such as Gussie, Panchen Lama and Dalai Lama according to discipline of Tibetan Buddhism in aspects of behavioral norms, moral rule, daily life and study experience for a certain temple or Dratsang. (bca' yig ni dgon pa'i nang gi mkhas grub gnyis 'dzoms kyi dge ba'i bshes dam pa'am rgyal ba paN chen lta bu'i bla sprul che ge mo zhig gis 'dul ba'i gzhung ltar dge 'dun gyi sde'i kun spyod dang slob gnyer byed stangs sogs kyi thad khrims bcas pa'i yi ge la bya)". 26 The author tries to talk about the content and characteristics of temple rules and social functions and roles of traditional temple rules.

\section{A. Content of Temple Rules}

As mentioned above, "temple rule of Tibetan Buddhism is set according to the principle of discipline, which is the extension and expansion of Buddhist discipline."27 From the texts of the history and the development history of temple rule of Tibetan Buddhism, it can be seen that content of temple rule has different points according to constitutor, purpose of formulation and applicable objects. It can be found after combing the contents of the temple rule in a broad sense that the common ground is the temple rule formulated for the area where Buddhism spreads and the temple rules made for a temple and the latter is more. However, regardless of the difference of the form and applicable area of temple rules, the content generally contains the following sections:

1) Eulogy: The narrative modes of all classics of Tibetan Buddhism have similarities, just as the prologue of temple rules are mainly eulogy. Its main content is to worship Triratna, and recall the kindness of predecessor.

\footnotetext{
26 Caijia, Cai Rangben, Xiangzhiduojie. Introduction to the Culture of Tibetan Buddhist Temples, Qinghai national publishing house, 2005: 91

$27 \quad$ Warhol dorje, Wei Changcheng. A Study of Temple rules in Tibetan Buddhist Temples. Tibetan Plateau Forum, 2012, 12(4): pp. 53.
}

The author divide it into three levels: First is eulogizing predecessors to highlight the traditional orthodoxy. The second is to explain the basis for formulating temple rules, and the third is to show the purpose of making temple rules.

2) Discussion on the order of Buddhist practice: This content can also be divided into two levels: one is to discuss the merit of study Buddhism; the other is to discuss the order of practice. The former guide monks and nuns to study Buddhism conscientiously by discussing why we should study Buddhism, what we study it for and what the interest to make clear the purpose of studying and proper attitude toward Buddhism practice is. The latter shows the process of studying Buddhism and the order and the regulated procedure in the process. For example, "temple rules for Nanjie Dratsang" of the seventh Dalai Lama (rnam rgyal grwa tshang gi bca 'yig) said: "The order of chanting is first sing the three conversion, and keeping four heavy precepts according to the regulation in "on entering Buddhism" 28

3) On abiding by the discipline and temple rules: Why do we need to formulate temple rules? Its ultimate goal is hoping that the monks can strengthen their individual studies of Buddhism through abiding by discipline and temple rules, which is also the core of temple rules. Since the content of this part is relevant complicated, the author summarize as following:

a) Norm for practice: The first ethics of monks and nuns is abandoning evil and promoting good, releasing all the life and cultivating one's original nature Sila is like practice according to the ritual procedure of Buddhism, so we need to move forward according to the order step by step. The basic order is the process from loose to tight and from simple to complex. The disciplines to be observed are also different in different practices. For example, for Bhikkhu, in the 253 section, the four heavy and 36 precepts are the most basic conduct and must be followed first.

b) Taboo of diet: Buddhism considers wine as one of the four heavy precepts as well as a basic discipline. In all temples rules of Tibetan Buddhism, drinking alcohol is resolutely forbidden, and the penalties for drinking are also relatively heavy.

c) Norms for dressing: This requirement includes wearing way and color of shabby, the length of hair, the height of the monk skirts, standard for holding chopsticks and bowl. Many temple rules even record the walking posture, knives and accessories and wearing jewelry.

d) Ritual procedure for dharma assembly: This includes the length of tum at the assembly and the law for lateness at assembly, the standards for the posture of holding instruments and the norms of chanting Dharma, and the consequences for the violation. As described in the temple rules of Drepung Monastery, "the dharma assembly must be held among the three snail sounds, and all should be

28 Archives of Tibet Autonomous Region. "Tibetan Local History Collection Temple Rules" (Tibetan version), Tibet people's publishing house, 2012, 1: 72 . 
at place. They can't dishevel clothes and hair, reverse seating and make loud noise and so on. 29 Ritual is one of the elements of religion, with a certain degree of sacredness and mystery. Most temple rules of Tibetan Buddhism have clear ceremony of dharma assembly and ritual procedure.

4) On the consequences of breaking the precept and getting out of line: Breaking the precept is caused by improper and negligent personal behavior. If the case is slight, the behavior can be corrected through repentance and penalties can be given accordingly. The slight penalties ranging from flogging, lighting butter lamp, and turning and kowtow, while the heavy one is excommunication.

5) Praying: As all the Buddhist scriptures, the temple rules end with a prayers, of which the content largely includes taking promotion of Dharma as the mission, relieving all living creatures, and praying for world peace.

\section{B. Characteristics of Temple Rules of Tibetan Buddhism}

As a management model of Buddhist temple, temple rules of Tibetan Buddhism have the following characteristics:

1) Temple rules are applicable to all monks and nuns: In Tibetan Buddhist temples, the scope of application of temple rules depends on the range set by the makers. The following points are included: (1) Temple rules established by religious leaders for a certain temple, such as the "Temple rules formulated by Fifth Dalai Lama for Xialu Temple" in 1676, "Temple rules of the hotaiwu Temple" made by Thirteenth Dalai Lama and so on. (2)Temple rules set by religious leaders for a certain region or the entire region where Tibetan Buddhism is spread, such as temple rules for the Potala Palace (po tA la'i bca' yig) made by Dalai the fifth in 1679. (3) The temple rules set by religious leaders for a certain Dratsang, such as the "temple rules for Nanjie Dratsang" (rnam rgyal grwa tshang gi bca 'yig) prescribed by the 7th Dalai Lama. (4) The temple rules prescribed by religious leaders for an activity point or temple, such as "rule for monks participating in the Dharma" (lha ldan cho 'phrul smon lam chen mo'i tshogs zhugs dge' dun spyi la bstsal ba'i bca 'yig) made by Dalai the fifth.

2) The constitutors of temple rules are usually prestigious: Buddhist leaders or tera shu Among them there are monks and laity, Such as the Dalai Lama and the Panchen Lama, eminent monks, abbot of monasteries, Tripa and other prestigious local officials.

3) Performer of temple rules - Guige: Each temple in the Tibetan area has its executor, which is called Guige "dge bskos" in term of Tibetan Buddhism. Their main task is to supervise the monks chanting and they have the right to punish. They usually visit the inside and outside of the temple, and supervise the behavior of every monk. Under normal circumstances, when the monks chant sutras,

29 Archives of Tibet Autonomous Region. "Tibetan Local History Collection Temple Rules" (Tibetan version), Tibet people's publishing house, 2001, 790-792.
"Guige" don't see them, holding a "wooden stick" or "iron stick", so some literature calls it "Iron Rod Lama."

4) The consequences of violating temple rules are usually repentance or punishment: Each temple rule includes a corresponding punishment system, in which slight case can repentance and the form is also varied, such as kowtow, collecting water, lighting butter lamp (m'chod me 'bul ba), or getting scolded and spur and so on. In serious case, they will be expelled.

5) The narrative style of temple rules - reasoning: In the way of narration, temple rule is not the legal norms of modern society, or regular like ancient Tibetan folk law. "Reasoning and encouraging goodness is its basic characteristic." 30 Most of the disciplines of the temple rules have the theoretical background of the Buddhist discipline and guidance of the local living environment. Therefore, although the religious discipline has the nature of folk law and social functions, its focus is imbued with enlightened meaning.

\section{Social Function of Traditional Temple Rules of Tibetan Buddhism}

Temple rules is the norm for the basic necessities of life of the monks in monastery, which can be summarized as the following aspects from the perspective of contents of temple rule and its functionality:

1) Temple rule is the extension and expansion of Buddhist discipline: As mentioned above, the main content of temple rules is Buddhist discipline. Temple rule is the rite and ritual procedure for life and self-regulation of monks and nuns. "Temple rule is the deduction and extensive explanation made for Buddhist discipline by demonstrating the interests and rationality of Sila".31

2) Temple rule is the code of conduct that monks and nuns must strictly observe: Temple rule is the standard regulation of rules of conduct for each Buddhist monk and nuns. In general, it plays a guiding and regulating role in the words and deeds of monks and nuns. For those monks and nuns who violate the temple rules, it plays a role of correcting words and deeds and educating through proper punishment.

3) Temple rule is the supplement to laws and folklore regulations: The law of a country is the minimum behavioral standards that people must follow generally. Abidance by law is the obligation of every citizen and the right of every citizen. Similarly, temple rule is the norm that every monk and nun must abide by. The control of temple rules and discipline over monks and nuns is stricter than the laws and folk regulations of the country.

\footnotetext{
30 Warhol dorje, Wei Changcheng. A Study of Temple rules in Tibetan Buddhist Temples. Tibetan Plateau Forum, 2012, 12(4): pp. 54.

31 Warhol dorje, Wei Changcheng. A Study of Temple rules in Tibetan Buddhist Temples. Tibetan Plateau Forum, 2012, 12(4): pp. 55.
} 


\section{CONCLUSION}

In short, the discipline of Tibetan Buddhism is the doctrinal dogmas that Buddhists must obey. The origin of the discipline can be traced back to the Buddhist precepts of ancient India. Introduction of Buddhism to Tibetan areas and its communication and development during the Tubo period was attributed to the support of Zanpu for development of Buddhism and the inclusive nature of Buddhism. However, from the perspective of the development of Tibetan Buddhist monasteries, discipline is also one of the intrinsic factors for its development. In the process of the development of Buddhist discipline and temple rules, discipline not only ensure that monks' behavior is in line with the doctrine ideal, but also promote followers who study and practice Buddhism more restrained and refined. The temple rules that gradually extend between different regions and groups make the periphery of Tibetan Buddhism more systematic, facilitate the temple management and promote its further development.

\section{REFERENCES}

[1] Yan Yaozhong. Buddhist discipline and Chinese Society. Shanghai Chinese Classics Publishing House, 2007, 11.

[2] Fan Chengda. Records of Wu prefecture, in "Tianfengyuan" article of Volume 32, cited Yan Yazhong: Buddhist discipline and Chinese Society, Shanghai Chinese Classics Publishing House, 2007, 11. pp. 2.

[3] Rita M,Gross:Buddhism After Patriarchy,State University of New york press,Albany 1993,p306.

[4] Wang Shouren. Collected works of Wang Yangming, Volume 9, The suggestion to meet Buddha hydrophobic, Shanghai Chinese Classics Publishing House, 1992: 294.

[5] Archie J Bamm. Comparative philosophy and comparative religion, Sichuan people's publishing house, 1996: 293.

[6] Wei Yingchun. Research on Precepts and Regulations of Buddhist Communities in Late Tang and Five Dynasties, Shanghai Chinese Classics Publishing House, 2015, 4. pp. 10

[7] Shangtian Tianrui. History of discipline. article 1 of chapter 1, three provinces in Tokyo Showa in the 25th year of Zhao He, pp.8

[8] Yan Yaozhong. Buddhist discipline and Chinese Society. Shanghai Chinese Classics Publishing House, 2007, 11. pp. 2.

[9] See S. 373 Datang three Tibetan question Xishe eye tower in The Collection of Dunhuang Social and Historical Documents in British Tibet, volume 2, Social Sciences Academic Press, 2003: 198.

[10] Zhang Jinghe. History of Sinology in Sweden, Chapter 1, Anhui literature and art publishing house. 1995, pp. 11.

[11] Fu Weixun. The dignity of death and the dignity of life, Peking University Press, 2006, pp.86.

[12] Archie J Bamm. Comparative philosophy and comparative religion, Sichuan people's publishing house, 1996: 184.

[13] Paul Williams:Mahayana Buddhism,Routledge,London and New York,1989,p:5

[14] Zhang Zhigang. Main idea of Religious research. Peking University Press, 2013, 1, pp. 20.

[15] (Yuan Dynasty) De Hui, Li Jiwu. monastic rules for Buddhists made by Laxiu Baizhang, Zhongzhou Ancient Books Publishing House, 2011, 7, pp. 1.

[16] (Yuan Dynasty) De Hui, Li Jiwu. monastic rules for Buddhists made by Laxiu Baizhang, Zhongzhou Ancient Books Publishing House, 2011, 7, pp. 3 .

[17] (Song Dynasty) Zong Ze, Su Jun. regulations of Zen garden. Zhongzhou Ancient Books Publishing House, 2006, 1, pp. 178.
[18] Zhang Zhigang. Main idea of Religious research. Peking University Press, 2013, 1, pp. 16.

[19] Warhol dorje, Wei Changcheng. A Study of Temple rules in Tibetan Buddhist Temples. Tibetan Plateau Forum, 2012, 12(4): pp. 51.

[20] Warhol dorje, Wei Changcheng. A Study of Temple rules in Tibetan Buddhist Temples. Tibetan Plateau Forum, 2012, 12(4): pp. 51.

[21] Warhol dorje, Wei Changcheng. A Study of Temple rules in Tibetan Buddhist Temples. Tibetan Plateau Forum, 2012, 12(4): pp. 51.

[22] Warhol dorje, Wei Changcheng. A Study of Temple rules in Tibetan Buddhist Temples. Tibetan Plateau Forum, 2012, 12(4): pp. 52.

[23] Suonan Cairang. General Introduction of thoughts of Tsongkhapa discipline. Qinghai Social Sciences, 1990 (5): 104

[24] Warhol dorje, Wei Changcheng. A Study of Temple rules in Tibetan Buddhist Temples. Tibetan Plateau Forum, 2012, 12(4): pp. 52.

[25] Archives of Tibet Autonomous Region. "Tibetan Local History Collection Temple Rules" (Tibetan version), Tibet people's publishing house, 2012, 1: 790.

[26] Caijia, Cai Rangben, Xiangzhiduojie. Introduction to the Culture of Tibetan Buddhist Temples, Qinghai national publishing house, 2005: 91

[27] Warhol dorje, Wei Changcheng. A Study of Temple rules in Tibetan Buddhist Temples. Tibetan Plateau Forum, 2012, 12(4): pp. 53.

[28] Archives of Tibet Autonomous Region. "Tibetan Local History Collection Temple Rules" (Tibetan version), Tibet people's publishing house, 2012, 1: 72 .

[29] Archives of Tibet Autonomous Region. "Tibetan Local History Collection Temple Rules" (Tibetan version), Tibet people's publishing house, 2001, 790-792.

[30] Warhol dorje, Wei Changcheng. A Study of Temple rules in Tibetan Buddhist Temples. Tibetan Plateau Forum, 2012, 12(4): pp. 54.

[31] Warhol dorje, Wei Changcheng. A Study of Temple rules in Tibetan Buddhist Temples. Tibetan Plateau Forum, 2012, 12(4): pp. 55. 